\title{
Process Parameters Optimization for Synthesis of Used Temple Oil Biodiesel Using Taguchi Technique
}

\author{
Sharanabasappa Saddu ${ }^{1 *}$, Sangshetty Kivade ${ }^{2}$ and Ramesha Devarahalli ${ }^{3}$ \\ ${ }^{1}$ VTU Belagavi, India
}

${ }^{2}$ Basavakalyan Engineering College Basavakalyan, India

${ }^{3}$ Mechanical Engineering, India

Submission: December 17, 2018; Published: January 18, 2019

*Corresponding author: Sharanabasappa Saddu, Research Scholar, VTU Belagavi, India

\begin{abstract}
Biomass resource is used to produce biodiesel which is an alternative renewable fuel. Physiochemical properties of biodiesel are very much close to the petroleum diesel fuel. This work deals with the study of transesterification for obtaining biodiesel from Used Temple Oil (UTO). To find the optimum yield of Used Temple Methyl Ester (UTOME) Taguchi methodology was selected. Under the influence of molar ratio, catalyst and reaction time ANOVA analysis have conducted. The result of this study in a maximum yield of UTOME as $94.51 \%$ with the optimal conditions of molar ratio 6:1 with $1.15 \%$ by weight of $\mathrm{NaOH}$ at 95 minutes. On the basis of "larger is better" the yield was analyzed.
\end{abstract}

\section{Introduction}

Biodiesel is produced by chemically reacting lipids like animal fat and vegetable oil etc. It is the exchanging process of the organic alkoxy group of an ester with another alcohol group [1]. Now a day's biodiesel has become very promising potential fuel due to its nature friendly qualities comparing with other conventional diesel [2]. Biodiesel is mainly produced from non-edible oil which is not used for human consumption. And this alterative resource could get bulk quantity by means of agricultural or forestry products. It also has the potential to replace conventional edible resource for the production of biodiesel [3]. Due to high viscosity and low volatility of vegetable oils create some problems of by applying directly to engines. The transesterification process is one of the proposed promising methods to convert vegetable oil to fatty acid alkyl ester which can be used in existing fuel based diesel engines [4]. To optimize the key factors of the transestrification process of Used Temple Oil methyl ester is the main objective of this study.

It is considered important to optimize the key process parameters like molar ratio of methanol-to-oil, catalyst concentration and time reaction as Used Temple Oil has not yet been more studied for the biodiesel production. Adding to this the properties of UTO and its methyl ester were determined and compared with ASTM D 7652 biodiesel standards and same was to analyze the experimental data in mini tab 18 . Based on specially designed orthogonal arrays the Taguchi method is a statically experimental design approach to evaluate entire process parameters and their effect on the process. This approach provides complete information about performance parameters influenced by factors and gives the smaller number of experimental sets. Compared with other methods, whichever analytically or experimentally this technique has been rarely taken [5]. To design experiments trials involved in production of sunflower methyl ester the Taguchi method uses an orthogonal array set for performing the fewest experiments was employed. The influencing parameters are found in the order of methanol $110 \mathrm{ml}$, catalyst convention $1.15 \mathrm{gm}(0.5 \% \mathrm{wt})$ and stirrer speed $1200 \mathrm{rpm}$, which produce the maximum yield of $96 \%$ according to the Taguchi method [6].

\section{Materials and Methods}

As per the tender advertisement by Department of Muzrai, Government of Karnataka, in 2016-17 the potential of Used Temple Oil was $18900 \mathrm{~kg}$ at Shree Renuka Yallamma Temple Soundatti, District Belagavi. This is oil potential from one temple only. The present study deals with the preparation of biodiesel from Used Temple Oil from Hanuman Temple and Marikamba Temple Sirasi, Uttarkannada, Karnataka. Used Temple Oil free fatty acid (FFA) content was found to be below $2 \%$. Therefore, direct transesterification with alkali catalyst was performed. The experiment was conducted on 4-stroke, single cylinder, water-cooled, compression ignition, AV1 Vertical diesel engine CI engine.

\section{Result and Discussion}

Taguchi orthogonal array method has been used for alkaline transesterification of UTO. Different parameters influencing the 


\section{International Journal of Environmental Sciences \& Natural Resources}

production yield of biodiesel production such as temperature, time for reaction, type of catalyst and its concentration, agitation or stirring speed, quality of the reactants and moisture content of the oil. Only the three most influencing parameters and three levels $(\mathrm{L}=3, \mathrm{~L}=3$ as shown in Table 1 have been considered in this study. The effects of the three chosen parameters at three different levels have been studied by conducting only nine experiments as per L9 orthogonal array shown in Table 2. In the present work the maximization of biodiesel yield is set as objectives, hence the larger, the better model has been used. The result show that the trial number 5 has the highest mean yield of $94.51 \%$ and trial number 6 has the lowest mean yield of $46.06 \%$. Table 1: Factor and Levels for Transesterification of Used Temple Oil.

\begin{tabular}{|c|c|c|c|}
\hline Factors & Level 1 & Level 2 & Level 3 \\
\hline Catalyst (\%) & 0.75 & 1.15 & 1.55 \\
\hline Molar ratio & $4.5: 1$ & $6: 1$ & $7: 1$ \\
\hline Time (min) & 35 & 65 & 95 \\
\hline
\end{tabular}

Table 2: L9 Orthogonal Array for Design of Experiments with Three Parameters at Three levels for Transestrification of Used Temple Oil.

\begin{tabular}{|c|c|c|c|c|}
\hline $\begin{array}{c}\text { Sl. } \\
\text { No }\end{array}$ & Catalyst (\%) & Molar Ratio & Time (min) & Yield (\%) \\
\hline 1 & 0.75 & $4.5: 1$ & 35 & 44.18 \\
\hline 2 & 0.75 & $6: 1$ & 65 & 75.91 \\
\hline 3 & 0.75 & $7: 1$ & 95 & 84.71 \\
\hline 4 & 1.15 & $4.5: 1$ & 65 & 86.88 \\
\hline 5 & 1.15 & $6: 1$ & 95 & 94.51 \\
\hline 6 & 1.15 & $7: 1$ & 35 & 46.06 \\
\hline 7 & 1.55 & $4.5: 1$ & 95 & 85.64 \\
\hline 8 & 1.55 & $6: 1$ & 35 & 47.82 \\
\hline 9 & 1.55 & $7: 1$ & 65 & 65.93 \\
\hline
\end{tabular}

Table 3: ANOVA Table for Transestrification of Used Temple Oil.

\begin{tabular}{|c|c|c|c|c|c|c|c|}
\hline Source & DF & Seq SS & Contribution & Adj SS & Adj MS & F value & P value \\
\hline \% of catalyst & 1 & 4.88 & $0.16 \%$ & 4.88 & 4.88 & 0.06 & 0.812 \\
\hline Molar ratio & 1 & 56.06 & $1.79 \%$ & 56.06 & 56.06 & 0.72 & 0.435 \\
\hline Time (min) & 1 & 2679.71 & $85.62 \%$ & 2679.71 & 2679.71 & 34.45 & 0.002 \\
\hline Error & 5 & 388.97 & $12.43 \%$ & 388.97 & 77.79 & & \\
\hline Total & 8 & 3129.61 & $100 \%$ & & & \\
\hline
\end{tabular}

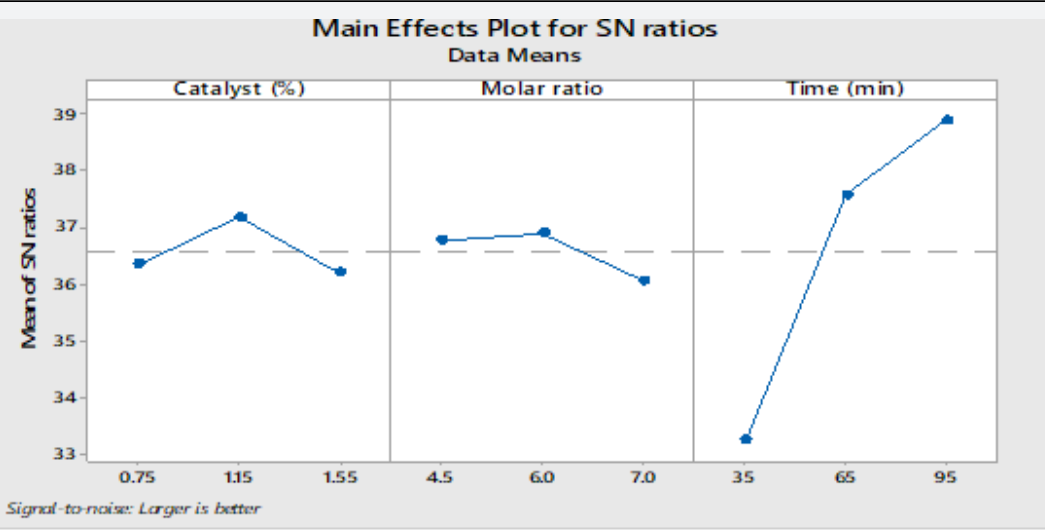

Figure 1: Main Effect Plot for SN ratios for the effect of Each Parameter at different levels.

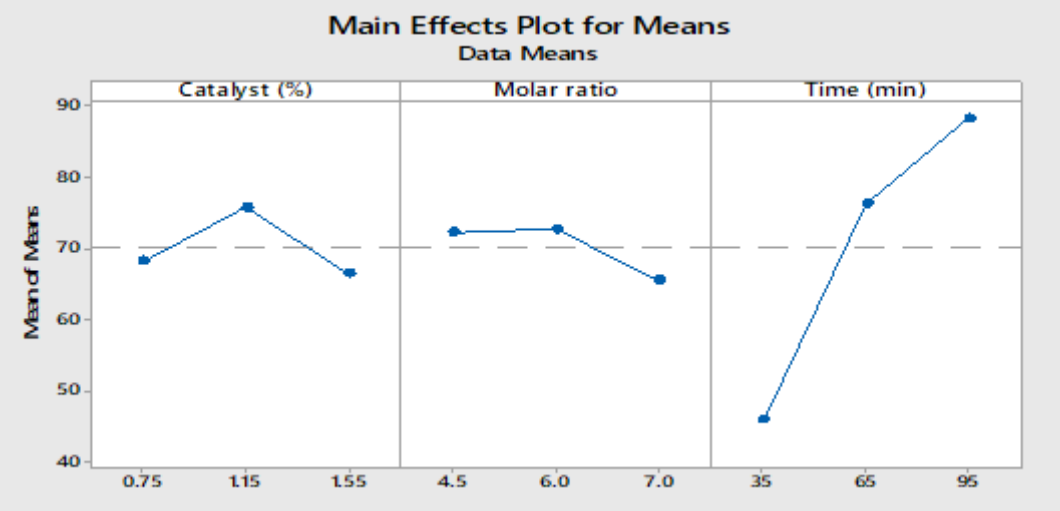

Figure 2: Main Effect Plot for Means for the effect of Each Parameter at different levels. 
The adequacy and signification of the developed regression model was tested using Analysis of variance (ANOVA) method. In ANOVA factors with $95 \%$ is considered as significant. This provided information on relative influence of parameters and their interactions with respect to the various results. According to this analysis, the most effective parameters with respect catalyst concentration, molar ratio and reaction time are mentioned. Table 3 shows response surface quadratic model for yield of Transestrification. The effects of each parameter at three different levels on UTOME in terms of yield are shown in Figure $1 \& 2$. A higher value of yield infers a greater influence of the particular parameter at that level. The maximum value in each graph specifies the optimum level of that particular parameter on the yield of UTOME.

Regression Equation \% of yield $=41.2-2.25 \%$ of catalyst (\%) - 2.43 Molar ratio + 0.704 Time (min).

Figure 3: Surface Plot for variation of Catalyst and Molar ratio with yield.

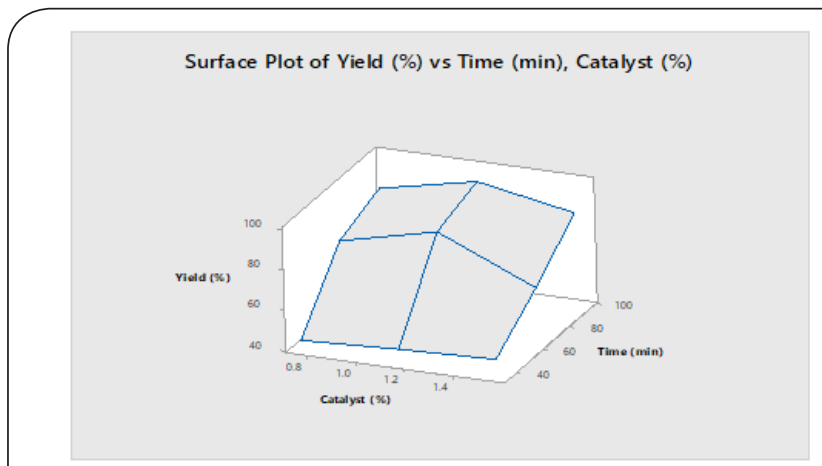

Figure 4: Surface Plot for variation of Catalyst and Time with yield.

It is observed from the (Table $4 \& 5$ ) that the time is most influencing factor, followed by catalyst and molar ratio. For carrying out ANOVA of response data, computation of sum of squares is essential. The effect of control parameters on biodiesel yield is shown in Figure $3 \& 4$. It can be seen from the surface plots that the contribution of time on biodiesel yield is significantly higher than the catalyst and molar ratio. This study selected the optimum parameter for high percentage by varying parameters through Taguchi method. The Taguchi method was an accurate and one of the efficient methods of determining the optimum parameters for high percentage yield of UTO methyl ester with an orthogonal array (L9) a total set nine experiments having three parameters each at three levels indicated. The contribution of each noise parameter estimated with the help of ANOVA. It was found that the optimum conditions for the UTO methyl ester production $94.51 \%$ by single stage transesterification were the molar ratio $6: 1$, catalyst concentration $1.15 \%$ and reaction time $95 \mathrm{~min}$.
Table 4: Response Table for Signal to Noise Ratios for Larger is better.

\begin{tabular}{|c|c|c|c|}
\hline Level & Catalyst (\%) & Molar Ratio & Time (min) \\
\hline 1 & 36.36 & 36.78 & 33.25 \\
\hline 2 & 37.18 & 36.90 & 37.59 \\
\hline 3 & 36.21 & 36.07 & 38.91 \\
\hline Delta & 0.98 & 0.83 & 5.65 \\
\hline Rank & 2 & 3 & 1 \\
\hline
\end{tabular}

Table 5: Response Table for Means.

\begin{tabular}{|c|c|c|c|}
\hline Level & Catalyst (\%) & Molar Ratio & Time (min) \\
\hline 1 & 68.27 & 72.23 & 46.02 \\
\hline 2 & 75.82 & 72.75 & 76.24 \\
\hline 3 & 66.46 & 65.57 & 88.29 \\
\hline Delta & 9.35 & 7.18 & 42.27 \\
\hline Rank & 2 & 3 & 1 \\
\hline
\end{tabular}

\section{References}

1. Khezeli A, Daneshfar A, Sahraei R (2016) A green Ultrasonic assisted liquid-liquid microextraction based on deep eutectic solvent for the HPLC-UV determination of ferulic, caffeic and cinnamic acid from olive, almond, sesame and cinnamon oil. Talanta 150: 577-585.

2. Kaul S, Kumar A, Bhatnagar AK, Goyal HB, Gupta AK (2003) Biodiesel A Clean and Sustainable Fuel for future, Scientific Strategies for Production of Non-Edible Vegetable Oils for Use as Biofuels, All India seminar on National Policy on Non- Edible Oils as Biofuels, IISc Bangalore, India.

3. Giakoumis EG, Rakopoulos CD, Dimaratos AM, Rakopoulos DC (2012) Exhaust Emissions of Diesel Engines Operating under Transient Conditions with Biodiesel fuels Blends, Progress in Energy and Combustion Science 38(5): 691-715. 
4. Puhan S, Vedaraman N, Ram BV (2005) Mahua oil (Madhuca Indica seed Oil) methyl ester as biodiesel- preparation and emission characteristics. Biomas Bioenergy 28(1): 87-93.

5. Rose PJ (1989) Taguchi techniques for quality engineering. McGrawHill Book Company, New York, USA.
6. Senthilkumar G, Balamurugan K (2014) Process parameters optimization for synthesis of methyl ester from sunflower oil using Taguchi technique Applied Science Innovations Pvt Itd India. Carbon Sci Tech 6/3: 22-29.

Your next submission with Juniper Publishers will reach you the below assets

- Quality Editorial service

- Swift Peer Review

- Reprints availability

- E-prints Service

- Manuscript Podcast for convenient understanding

- Global attainment for your research

- Manuscript accessibility in different formats (Pdf, E-pub, Full Text, Audio)

- Unceasing customer service

Track the below URL for one-step submission https://juniperpublishers.com/online-submission.php 